\title{
The Use of a Plate Conveyor for Transporting Aluminum Cans in the Food Industry
}

\author{
Jacek Caban' ${ }^{1}$ Iwona Rybicka² \\ 1 University of Life Sciences in Lublin, Faculty of Production Engineering, Department of Agricultural, Forestry \\ and Transport Machines, 28 Głęboka, 20-612 Lublin, Poland \\ 2 Lublin University of Technology, Faculty of Mechanical Engineering, Nadbystrzycka 36, 20-618 Lublin, Poland \\ * Corresponding author's e-mail: i.rybicka@pollub.pl
}

\begin{abstract}
The food industry is characterized by specific technical and technological conditions. The sanitary and epidemiological considerations play a very important role as well, and the materials used in production must meet the appropriate requirements. In the case of transport operations, the above-mentioned criteria must also be met. The article presents the problems of transporting beverages in aluminum can packaging using a plate conveyor. Depending on the efficiency of the production machines, the type of material (product packaging), the location of the center of gravity and the angle of friction, the parameters of the conveyor operation were determined.
\end{abstract}

Keywords: internal transport, efficiency, packaging

\section{INTRODUCTION}

The food industry is characterized by specific process conditions like: technical and technological conditions, sanitary and epidemiological considerations as well as suitable materials used in the production process. A proper choice of the technological and organizational parameters of the production processes enables more efficient and effective production of goods [17]. Traditionally, the research on the manufacturing processes was mainly conducted to the improve efficiency and accuracy and to lower the cost [12]. One of the modern challenges in the field of designing the manufacturing systems is to determine the optimal level of their flexibility from the point of view of the production tasks being performed. Whether or not a production process to be executed is capable of achieving the assumed performance parameters depends, among others, on the reliability of the machines and technological devices that make up the system under design [6]. Furthermore, a sustainable production line must also be balanced as it leads to lower costs, good production environments and green manufacturing [22].

The production operations within an automated production line would be impossible if they did not cooperate with the means of continuous transport. Transportation plays a very important role in the logistics of manufacturing systems $[3,11]$. The concept of transportation control is not constrained to fully-automated systems [8]. Bulk and mass production is being replaced by small batch production [16]. Conveyors and manipulators complete the production process and ensure the required process efficiency [1]. Depending on the conveyors construction, they are used to transport unit loads and loose materials carried in bulk. Belt conveyors mounted in a transport system consisting of conveyor modules with and without drive, turntables or arches are in common use [4]. The support and drive elements are subjected to variable loads resulting from the possibility of transporting loads of various shapes and weights on one conveyor [10]. Furthermore, the additional operating conditions of the conveyors like reduction of noise and vibrations are defined by 
the normative requirements $[13,15]$. In the case of the transport operations on the production line, there are many problems related to both transport operations as well as additional processes, marking, identification, etc. In $[9,14]$, algorithms and design procedures are described as well as the ways to control the assembled transport system in terms of eliminating bottlenecks causing queues at junction points. In order to increase the efficiency of internal transport processes as well as the correct location and tracking of transported goods, the RFID technology is used [2, 20].

In addition, transport conveyors are used in many industrial applications and logistics processes, among others: heavy industry [21, 22], agriculture [17], food and processing industry [7], in sorting areas of courier companies [5, 20], warehouse [19] etc.

One of the most frequently used type of conveyor for transporting unit loads in the food industry (e.g. bottles, cans) is a plate conveyor. The load-bearing elements of the plate conveyors are train chains, usually two-legged, connected to each other by plates, on which the transported material is moved. Plate conveyors are used not only as means of transport, but also as buffering conveyors; they also operate jointly with other technological devices, for example for filling, labeling, closing, sorting etc. Due to the fact that they can operate at high temperatures and their supporting elements are characterized by the resistance to chemical products, they are widely used in the food and chemical industry.

The article presents the selected results of the laboratory tests of a plate conveyor during the transport of aluminum cans with a drink. The conveyor as a mechatronic device consists of a physical mechanical model, a motion device (motor + gearbox) and a controller that controls the movement of the motor and the conveyor itself [18].

\section{METHODOLOGY}

Figure 1 presents the PP-4/2014 plate conveyor used in the research on determining the transport efficiency of aluminum cans packaging.

The plate conveyor is driven by an electric motor, type SK1SI40-IEC80-80S/4 TF from "NordDrivesystems" with a capacity of $0.55 \mathrm{~kW}$ and a rated voltage of $380 \mathrm{~V}$. Using a control and measurement system consisting of an iG5A inverter, the engine speed and controller with display were adjusted. The following additional equipment was used during the tests:

- ArcoMaster electronic protractor with a spirit level,

- Electronic caliper,

- AXIS BA30C platform scale.

The transport efficiency tests were conducted for load unit (aluminum cans with a drink of 0.33 liter capacity) - Table 1 , with three angles of inclination of the transport module $3^{\circ}, 6^{\circ}$ and $9^{\circ}$. The following parameters were recorded during the test: frequency of the inverter, linear speed of the conveyor belt, rotational speed of the drive motor of the conveyor, loading time, general transport time, distance between loads.

The plate conveyor efficiency $Q$ was calculated on the basis of equation for the unit load:

$$
Q=b G v / a
$$

where: $G$ - unit weight of the load $[\mathrm{kg}]$,

$V$ - linear speed of the conveyor belt $[\mathrm{m} / \mathrm{s}]$,

$\mathrm{a}$-distance between loads [m].

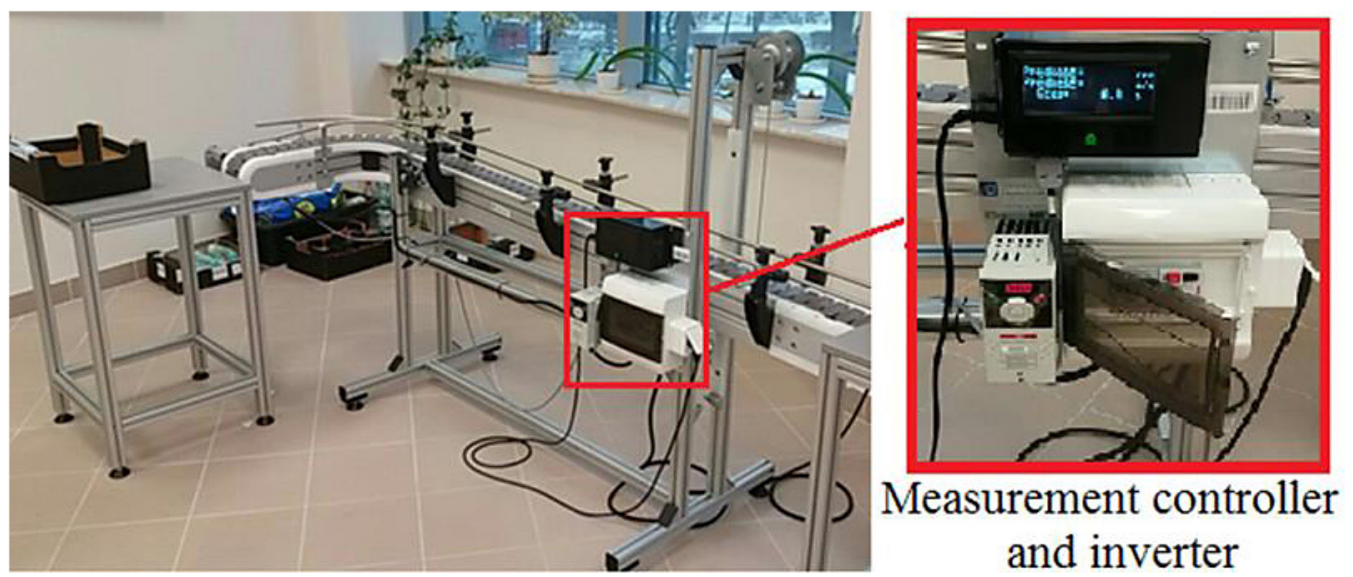

Fig. 1. PP-4/2014 plate conveyor 
Table 1. Characteristics of aluminum cans used during tests

\begin{tabular}{|c|c|c|c|c|}
\hline \multirow{2}{*}{ Weight $[\mathrm{kg}]$} & \multirow{2}{*}{ Height $[\mathrm{mm}]$} & \multicolumn{2}{|c|}{ The diameter of the package } & \multirow{2}{*}{ Contact ${\operatorname{area~}\left[\mathrm{mm}^{2}\right]}^{$\cline { 3 - 4 }$}$} \\
\cline { 3 - 4 } & 115 & Min. $[\mathrm{mm}]$ & Max. $[\mathrm{mm}]$ & 301.2 \\
\hline 0.35 & 54 & 65.5 & 3 \\
\hline
\end{tabular}

\section{RESULTS AND DISCUSSION}

Tables $2-4$ present the results of the transport conditions tests on a plate conveyor for aluminum cans with a drink.

In the Figures 2-4 are shown the results of calculations of plate conveyor efficiency at three values of the conveyor transport module inclination angle concerning the plate conveyor speed.
Figure 5 presents the comparison of the plate conveyor efficiency results for three tested transport module angles $\left(3^{\circ}, 6^{\circ}, 9^{\circ}\right)$, of the transporting the aluminum cans.

While analyzing the graphs, it can be seen that their course for aluminum cans retains repeatability for the inclination angle of the $3^{\circ}$ and $6^{\circ}$ transport module. In both graphs, the extreme is located in the speed range from 0.4 to $0.43 \mathrm{~m} / \mathrm{s}$.

Table 2. The results of measurements of transporting aluminum cans at the angle of inclination of the transporting module equal to $3^{\circ}$

\begin{tabular}{|c|c|c|c|c|c|c|}
\hline \multirow{2}{*}{ No. } & \multirow{2}{*}{$\begin{array}{c}\text { Frequency of the } \\
\text { inverter }[\mathrm{Hz}]\end{array}$} & $\begin{array}{c}\text { Loading time } \\
{[\mathrm{s}]}\end{array}$ & $\begin{array}{c}\text { General } \\
\text { transport time } \\
{[\mathrm{s}]}\end{array}$ & $\begin{array}{c}\text { Distance } \\
\text { between loads } \\
{[\mathrm{m}]}\end{array}$ & \multicolumn{2}{|c|}{ Conveyor speed } \\
\cline { 6 - 7 } & 10 & 1.2 & 17.2 & 0.27 & 0.28 & 39 \\
\hline 1 & 11 & 1.2 & 16.5 & 0.28 & 0.31 & 43 \\
\hline 2 & 12 & 1.1 & 15.4 & 0.28 & 0.34 & 47 \\
\hline 3 & 13 & 1.1 & 14.7 & 0.30 & 0.37 & 51 \\
\hline 4 & 14 & 1.0 & 14.3 & 0.30 & 0.4 & 55 \\
\hline 5 & 15 & 1.0 & 13.3 & 0.35 & 0.43 & 60 \\
\hline 6 & 16 & 1.0 & 13.1 & 0.37 & 0.46 & 64 \\
\hline
\end{tabular}

Table 3. The results of measurements of transporting aluminum cans at the angle of inclination of the transporting module equal to $6^{\circ}$

\begin{tabular}{|c|c|c|c|c|c|c|}
\hline \multirow{2}{*}{ No. } & \multirow{2}{*}{$\begin{array}{l}\text { Frequency of the } \\
\text { inverter }[\mathrm{Hz}]\end{array}$} & \multirow{2}{*}{$\begin{array}{l}\text { Loading time } \\
\text { [s] }\end{array}$} & \multirow{2}{*}{$\begin{array}{c}\text { General } \\
\text { transport time } \\
{[\mathrm{s}]}\end{array}$} & \multirow{2}{*}{$\begin{array}{c}\text { Distance } \\
\text { between loads } \\
{[\mathrm{m}]}\end{array}$} & \multicolumn{2}{|c|}{ Conveyor speed } \\
\hline & & & & & Linear $[\mathrm{m} / \mathrm{s}]$ & Rotational [rpm] \\
\hline 1 & 10 & 1.1 & 18.3 & 0.25 & 0.28 & 39 \\
\hline 2 & 11 & 1.1 & 17.4 & 0.27 & 0.31 & 43 \\
\hline 3 & 12 & 1.1 & 15.9 & 0.27 & 0.34 & 47 \\
\hline 4 & 13 & 1.1 & 15.7 & 0.30 & 0.37 & 51 \\
\hline 5 & 14 & 1.0 & 14.8 & 0.30 & 0.40 & 55 \\
\hline 6 & 15 & 1.0 & 15.1 & 0.30 & 0.43 & 60 \\
\hline 7 & 16 & 1.0 & 15.1 & 0.35 & 0.46 & 64 \\
\hline
\end{tabular}

Table 4. The results of measurements of transporting aluminum cans at the angle of inclination of the transporting module equal to $9^{\circ}$

\begin{tabular}{|c|c|c|c|c|c|c|}
\hline \multirow{2}{*}{ No. } & \multirow{2}{*}{$\begin{array}{c}\text { Frequency of the } \\
\text { inverter }[\mathrm{Hz}]\end{array}$} & \multirow{2}{*}{$\begin{array}{c}\text { Loading time } \\
{[\mathrm{s}]}\end{array}$} & $\begin{array}{c}\text { General } \\
\text { transport time } \\
{[\mathrm{s}]}\end{array}$ & $\begin{array}{c}\text { Distance } \\
\text { between loads } \\
{[\mathrm{m}]}\end{array}$ & \multicolumn{2}{|c|}{ Conveyor speed } \\
\cline { 6 - 7 } & 10 & 1.1 & 18.4 & 0.30 & 0.28 & 39 \\
\hline 1 & 11 & 17.8 & 0.32 & 0.31 & 43 \\
\hline 3 & 12 & 1.1 & 18.0 & 0.34 & 0.34 & 47 \\
\hline 4 & 13 & 1.1 & 17.1 & 0.35 & 0.37 & 51 \\
\hline 5 & 14 & 1.1 & 16.5 & 0.37 & 0.40 & 55 \\
\hline 6 & 15 & 1.1 & 17.3 & 0.42 & 0.43 & 60 \\
\hline 7 & 16 & 1.1 & 16.5 & 0.47 & 0.46 & 64 \\
\hline
\end{tabular}




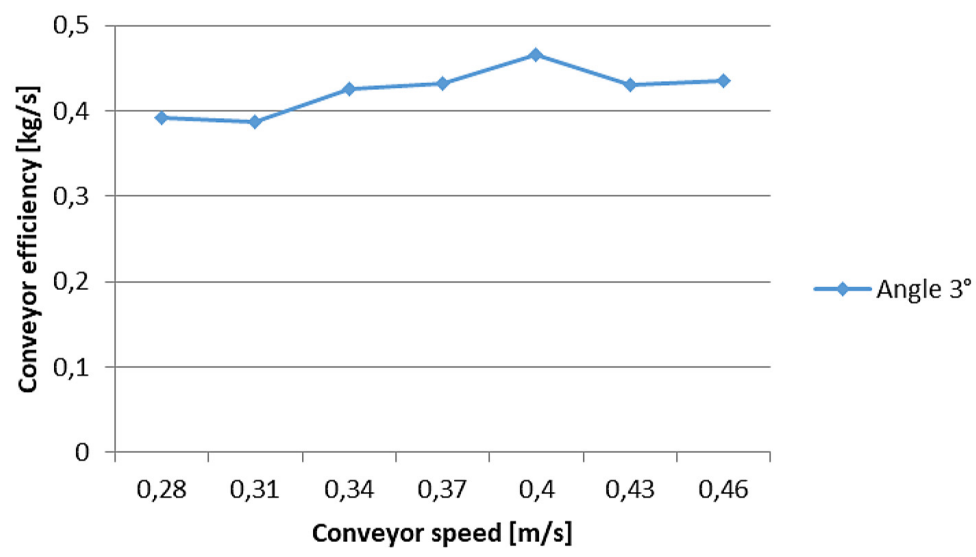

Fig. 2. The dependence of the value of the plate conveyor efficiency on the conveyor speed at the inclination angle of the transport module of $3^{\circ}$

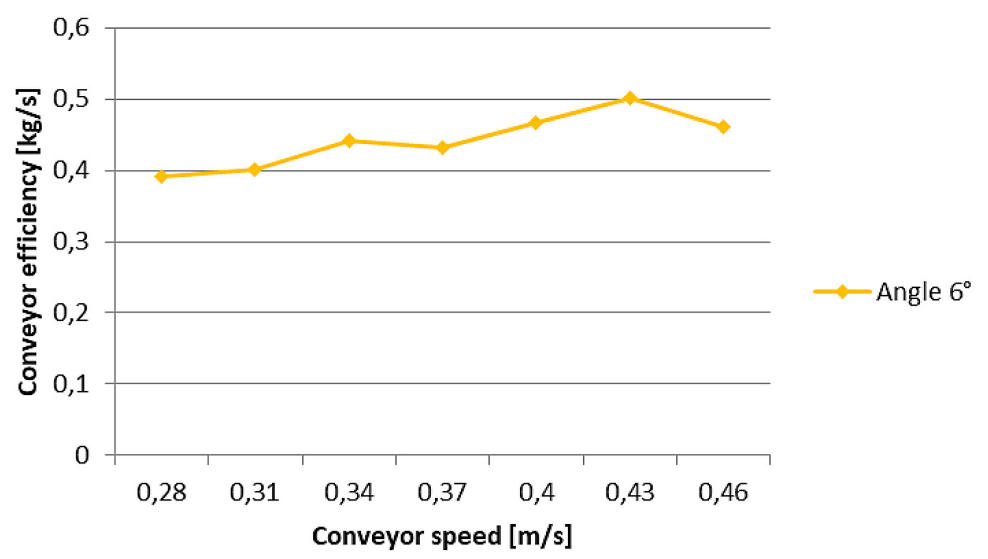

Fig. 3. The dependence of the value of the plate conveyor efficiency on the conveyor speed at the inclination angle of the transport module of $6^{\circ}$

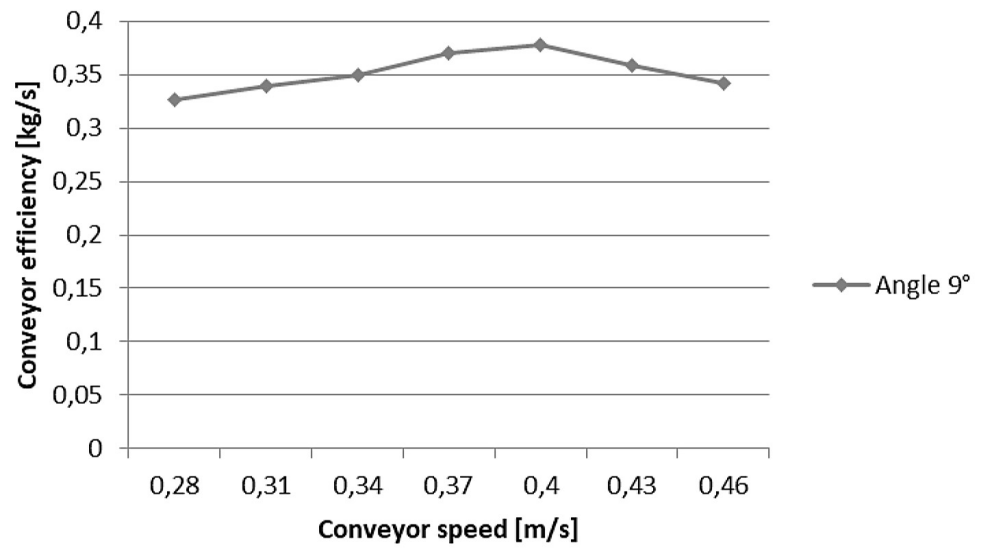

Fig. 4. The dependence of the value of the plate conveyor efficiency on the conveyor speed at the inclination angle of the transport module of $9^{\circ}$

The curve at an angle of $6^{\circ}$ has a stable increase without sudden fluctuations, to the speed range to $0.43 \mathrm{~m} / \mathrm{s}$, at $0.46 \mathrm{~m} / \mathrm{s}$ slight drop in the conveyor efficiency is observed. The curve at an angle of $3^{\circ}$ has a stable increase without sudden fluctuations, to the speed range to $0.4 \mathrm{~m} / \mathrm{s}$, at next speed value a drop in the conveyor efficiency can be observed. The plate conveyor efficiency is the smallest for setting the transport module at an angle of $9^{\circ}$. 


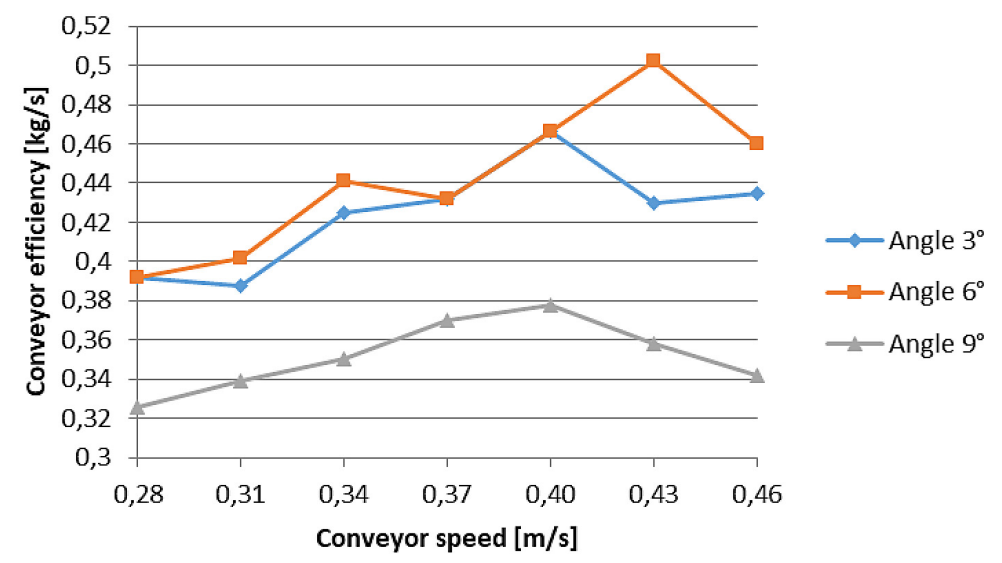

Fig. 5. A comparison of the plate conveyor efficiency results for three transport module angles

\section{CONCLUSIONS}

In this study, the results of the plate conveyor efficiency obtained during the transport of aluminum cans with the beverage at three angles of inclination of the transport module in the upward direction were presented. On the basis of the conducted study, it was noticed that the conveyor efficiency decreased with the increase of the inclination angle of the transport module. The most noticeable decrease of the conveyor efficiency occurred with the angle of inclination of the transport module amounting to $9^{\circ}$. The area between 6 and 9 degrees is interesting, which would have to be investigated, because in this range there was the greatest reduction in the plate conveyor efficiency, up to $20 \%$.

During the transport of packaging in the form of aluminum cans at higher belt speeds, a slip was observed between the conveyor plate and the contact surface with the load when placing the cans on the conveyor plates. This phenomenon is caused by the difference in the velocity vectors and the direction of placing aluminum cans on the plates and the speed of conveyor movement. During the transport on the plate conveyor, the location of the center of gravity of the load and the shape of its contact surface (bottom of the package) are also important.

\section{REFERENCES}

1. Blatnicky, M., Dizo, J., Blatnicka, M., Svoboda, M. (2017). Design of a robot manipulator working screw revolutions. 23rd International Conference on Engineering Mechanics Svratka, Czech Republic, MAY 15-18, 2017. Engineering Mechanics, 166-169.
2. Buffi, A., Nepa, P., Lombardini, F. (2015). A PhaseBased Technique for Localization of UHF-RFID Tags Moving on a Conveyor Belt: Performance Analysis and Test-Case Measurements. IEEE Sensors Journal, 15,1, 387-396. doi: 10.1109/ JSEN.2014.2344713

3. Burduk, A., Musial, K. (2016). Optimization of chosen transport task by using generic algorithms. Lecture Notes in Computer Science. 9842, 197-205.

4. Cempírek, V., Gašparík, J., Zitrický, V., Blaho, P. (2018). Control of modular conveyor and automated handling devices interconnection. Advanced in Science and Technology Researched Journal, 12, 3, 210-221. doi: 10.12913/22998624/94963

5. Droździel, P., Winska, M., Madlenak, R., Szumski, P. (2017). Optimization of the position of the local distribution centre of the regional post logistics network. Transport Problems, Vol. 12, 3, 43-50.

6. Gola, A. (2019). Reliability analysis of reconfigurable manufacturing system structures using computer simulation methods. Eksploatacja i Niezawodnosc - Maintenance and Reliability, 21 (1), pp. 90-102.

7. Gola, A., Nieoczym, A. (2017). Application of OEE Coefficient for Manufacturing Lines Reliability Improvement. Proceedings Of The 2017 International Conference On Management Science And Management Innovation (MSMI 2017). Edited by: Wee, H.M., Yuan, C. AEBMR-Advances in Economics Business and Management Research, Vol. 31, 189-194.

8. Gola, A., Kłosowski, G. (2018). Application of Fuzzy Logic and Genetic Algorithms in Automated Works Transport Organization. Advances in Intelligent Systems and Computing, 620, 29-36.

9. Johnstone, M., Creighton, D., Nahavandi, S. (2015). Simulation-based baggage handling system merge analysis. Simulation Modelling Practice and Theory, 53, 45-59.

10. Kobayashi, Y., Toya, K. (2007). Effect of belt 
transport speed and other factors on belt mistracking. Microsystem Technologies, 13, 8-10, 1325-1330.

11. Kowalski, A., Marut, T. (2012). Hybrid Methods Aiding Organisational and Technological Production Preparation Using Simulation Models of Nonlinear Production Systems. Lecture Notes in Computer Science. 7209, 259-266.

12. Linke, B.S., Corman G.J., Dornfeld, D.A., Tonissen, S. (2013). Sustainability indicators for discrete manufacturing processes applied to grinding technology. Journal of Manufacturing Systems 32 556- 563.

13. Liptai, P., Lumnitzer, E., Moravec, M., Piňosová, M. (2018). Analysis and Classification of Noise Sources of Conveyor Systems by Sound Visualizing on the Postal Package Sorting Line. Advances in Science and Technology Research Journal, 12,4, 172-176. doi: https://doi.org/10.12913/22998624/100348

14. Piątkowski, T., Sempruch, J., Tomaszewski T. (2013). Zagadnienie bezpieczeństwa ładunków jednostkowych w zautomatyzowanych liniach sortujących. Autobusy, 3, 883-891.

15. Piňosová, M., Andrejiová, M., Liptai, P., Lumnitzer, E. (2018). Objective and subjective evaluation of the physical risk factors near a conveyor system. Advanced in Science and Technology Researched Journal, 12, 3, 188-196. doi: 10.12913/22998624/94964

16. Rudawska, A., Čuboňova, N., Pomarańska, K., Stanečková, D, Gola, A. (2016). Technical and Organizational Improvements of Packaging Production Processes. Advances in Science and Technology.
Research Journal. 10 (30), 182-192.

17. Rudawska, A., Flechsig, A., Miturska, I. (2019). Technical and Organisational Changes in a Selected Production Process. MATEC Web of Conferences 252, 06014.

18. Ružarovský, R., Holubek, R., Rolando Delgado Sobrino, R., Janíček, M. (2018). The Simulation of Conveyor Control System Using the Virtual Commissioning and Virtual Reality. Advanced in Science and Technology Researched Journal, 12, 4, 164-171. doi: https://doi.org/10.12913/22998624/100349

19. Stopka, O., Luptak, V. (2018). Optimization of Warehouse Management in the Specific Assembly and Distribution Company: a Case Study. Nase More, 65, 4, pp. 266-269.

20. Svadlenka, L., Dobrodolac, M., Blagojevic, M. (2016). Application of tracking technologies in the postal system. Proceedings Of The Third International Conference On Traffic And Transport Engineering (ICTTE), Edited by: Cokorilo, O. 980-990.

21. Tropp, M., Tomasikova, M., Bastovansky, R., Krzywonos, L., Brumercik, F. (2017). Concept of deep drawing mechatronic system working in extreme conditions. 12th International Scientific Conference Of Young Scientists On Sustainable, Modern And Safe Transport. Edited by: Bujnak, J., Guagliano, M., Procedia Engineering, 192, 893-898.

22. Zhou, Z., Dou, Y., Sun, J., Jiang, J., Tan, Y. (2017). Sustainable Production Line Evaluation Based on Evidential Reasoning. Sustainability, 9, 1811. 